\title{
Remotely delivered immunocontraception in free-roaming feral burros (Equus asinus)
}

\author{
J. W. Turner, Jr ${ }^{1}$, I. K. M. Liu ${ }^{2}$ and J. F. Kirkpatrick ${ }^{3}$

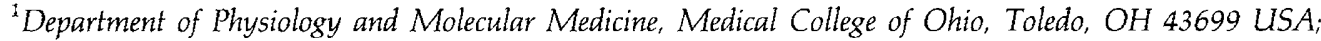 \\ ${ }^{2}$ Department of Population, Health and Reproduction, School of Veterinary Medicine, University of \\ California, Davis, CA 59616, USA; and ${ }^{3}$ Science and Conservation Biology Program, ZooMontana, \\ Billings, MT 59108, USA
}

\begin{abstract}
Regulation of local overpopulations of free-roaming feral equids is in demand worldwide for ecological balance and habitat preservation. Contraceptive vaccines have proven effective in feral horses, which breed seasonally, but no data are available for equids such as the burro, which is reproductively active all year round. In the present study, 27 individually identified female feral burros (Equus asinus) roaming free in Virgin Islands National Park (St John, US Virgin Islands; Lesser Antilles) were remotely treated with pig zonae pellucidae (PZP) vaccine. Between January and May, 16 burros were darted with a $1 \mathrm{ml}$ emulsion of PZP plus Freund's adjuvant. Ten to twelve months later each treated burro was given a single booster injection of PZP plus adjuvant to maintain contraception through a second year. Eleven adult untreated jennies served as controls. Beginning one year after initial vaccination, these burros were monitored for pregnancy and foal production. Collection of data to determine treatment effect was not begun until 12 months after initial treatment to ensure that pregnancies existing before vaccination were not included. Pregnancy was assessed using previously validated methods for steroid metabolite measurement in fresh faecal samples. None of the PZP-treated burros produced foals between 0 and 12 months after the last inoculation. One PZP-treated burro tested positive for pregnancy at 10 months after the final inoculation. During this same period, six of 11 untreated burros tested pregnancypositive, and four were observed with foals. There was no difference in pregnancy rates among treated, control and randomly sampled jennies between 12 and 24 months after the last inoculation. The results demonstrate that, in free-roaming feral burros that are reproductively active all year round: (1) burros can be accessed for remotely delivered PZP vaccination; (2) PZP contraception is effective; (3) PZP contraception is reversible; and (4) pregnancy can be reliably detected by faecal steroid analysis.
\end{abstract}

\section{Introduction}

Reducing fertility among free-roaming horses (Equus caballus) and feral burros (Equus asinus) has been the goal of numerous studies in the United States over the past two decades. Initial experiments focused on contraceptive steroids which were delivered as injectable, sustained-release (microencapsulated) compounds (Kirkpatrick et al., 1982; Turner and Kirkpatrick, 1982) or Silastic ${ }^{\mathbb{R}}$ implants (Plotka et al., 1989). All of these methods resulted in various degrees of pharmacological success but the microencapsulated steroids required extremely large doses and the Silastic ${ }^{(\hat{)}}$ implants required restraint and surgery. In addition, there is concern about steroid-induced pathologies, alteration of behaviour, and the passage of steroids through the food chain when they are used to prevent conception in free-roaming animals (Turner and Kirkpatrick, 1991).
An alternative to steroid-induced fertility control in equids is immunocontraception. Solubilized pig zonae pellucidae (PZP) injections delivered remotely inhibited fertility in captive feral mares (Liu et al., 1989), and free-roaming wild mares (Kirkpatrick et al., 1990a). In a follow-up experiment, 14 previously treated mares were given a single PZP booster inoculation, and 13 of the 14 failed to produce foals (Kirkpatrick et al., 1991a). These studies also showed that immunosuppression, which usually accompanies pregnancy in mammals, does not interfere with the contraceptive effects of the vaccine and that the vaccine is safe for use in animals that are already pregnant.

Another advantage of the PZP vaccine is the protein nature of the contraceptive antigen. This characteristic precludes the possibility of passage of the antifertility agent through the food chain. In any realistic management by contraception, some treated animals will die from natural causes and a variety of scavengers will feed upon the carcasses. Protein, unlike steroids (particularly synthetic steroids), cannot be passed 
along intact to the predators' tissues and cannot accumulate therein. This is an important environmental consideration where large-scale management of wild or feral equids is contemplated (Turner and Kirkpatrick, 1991).

The success of PZP vaccine in suppressing fertility appears to be via its ability to inhibit fertilization (Sacco et al., 1984). The PZP consists of four glycoproteins. At least one of these, ZP3, is the receptor molecule for sperm surface molecules (Florman and Wassarman, 1985). Antibodies raised against PZP are thought to block the sperm receptor sites on the equine zona pellucida, possibly by steric hindrance (Skinner et al., 1984), therefore preventing fertilization.

An equid that has not been tested for effectiveness of PZP contraception is the burro. This hardy equid, with a gestation of 11 months, has been a successful reproducer in many harsh environments (McKnight, 1958), and is a problem feral animal in several parts of the world including North America, Australia and Africa (Woodward, 1979). Presently there is a feral burro population inhabiting the island of St John, United States Virgin Islands, which is the site of Virgin Islands National Park. The burros in this population, locally referred to as 'donkeys', are Equus asinus, and no mules are known to be present. The population is reportedly in excess of 250 and is expanding (Nellis et al., 1986). The circumstances of fixed land mass and expanding populations, both human and burro, have raised interest on the part of the National Park Service to investigate means of regulating feral burro numbers on St John. This situation offered an opportunity to evaluate PZP immunocontraception in an equid that is reproductively active throughout the year (Nellis et al., 1986). An additional opportunity available with this burro population was to determine whether pregnancy could be detected via measurement of concentrations of specific steroid metabolites in faecal samples. Previous studies have shown that pregnancy is consistently associated with high concentrations of oestrone sulfate, a group of progesterone metabolites, and total oestrogens in extracts of fresh faeces in free-roaming feral horses (Kirkpatrick et al., 1990b, 1991b) and in several other species (Loskutoff et al., 1982; Lasley and Kirkpatrick, 1991).

The goals of the present study of immunocontraception of feral burros inhabiting Virgin Islands National Park (VINP) were to determine: (1) the accessibility to feral burros for remote vaccination; (2) the deliverability of $\mathrm{PZP}$ vaccine to feral burros by dart; (3) the contraceptive effectiveness of the PZP vaccine in feral burros; (4) the reversibility of the contraceptive effect in feral burros; and (5) the capability for pregnancy testing of feral burros through faecal steroid measurement.

\section{Materials and Methods}

\section{Study area}

The study was carried out on the Caribbean island of St John in the US Virgin Islands, a part of the Lesser Antilles island group, located at $18^{\circ} 20^{\prime} \mathrm{N}$ latitude and $65^{\circ} 45^{\prime} \mathrm{W}$ longitude. St John is approximately $11 \mathrm{~km} \times 5 \mathrm{~km}$, covering an area of 5180 ha. The majority of the burros included in the study inhabit Virgin Islands National Park, which, in somewhat checkerboard fashion, comprises $57 \%$ of the land area of
St John. The climate is relatively constant throughout the year with steady trade winds, temperatures normally ranging from $18^{\circ}$ to $32^{\circ} \mathrm{C}$, and an average $75 \%$ humidity. The topography is rugged, characterized by deep valleys, high ridges and several major drainage basins. Sixty-three per cent of the island is covered by four types of dry evergreen forest, and the remainder is covered by moist forest, vegetation secondary to recent human activity, pasture and urban development. Burros tend to be concentrated in basin areas, but can be found in every habitat type, including urban areas. The drainage basins contain fresh and brackish water ponds, which the burros use for drinking water.

\section{Burro identification and access}

The present study used 27 adult female burros ranging in weight from approximately $90 \mathrm{~kg}$ to $115 \mathrm{~kg}$. Sixteen of these were treated with contraceptive, and 11 were untreated controls. Half of the control jennies were in the same family groups as treated jennies. Individual burros were identified on the basis of coat colour and shading, body and head size and shape, and unique markings or permanent scars (Turner et al., 1981). This method of identification was initially time intensive but proved highly reliable and consistent across the study period. Access to burros to provide treatment via remotely delivered dart was accomplished by the establishment and regular use of bait stations. These 'stations' were merely ground sites along paths frequented by burros, usually in flat areas and within $10 \mathrm{~m}$ of brushy sanctuary. A mixture of grain, hay and molasses was placed at the sites daily. Regular use of these bait stations occurred within 2 weeks.

\section{Pig zonae pellucidae vaccine preparation}

The pig zonae pellucidae vaccine was prepared as described by Liu et al. (1989) and stored frozen in $0.5 \mathrm{ml}$ aliquots until used. Burros were given an initial one- or two-injection PZP treatment and, after 10-12 months, were given a one-injection PZP booster treatment. Initial treatment consisted of: (I) two separate injections (3 weeks apart) of a $1.0 \mathrm{ml}$ emulsion, containing $65 \mu \mathrm{g}$ PZP plus Freund's complete (first injection) or incomplete (second injection) adjuvant $(n=13)$; or (2) a single injection containing $130 \mu \mathrm{g}$ PZP emulsified in Freund's complete adjuvant. The PZP for the single injection was present in two forms: $65 \mu \mathrm{g}$ unsequestered and $65 \mu \mathrm{g}$ sequestered in 10-50 $\mu \mathrm{m}$ diameter microspheres of biodegradable lactide and glycolide in a 1:1 ratio $(n=3)$. The polymer microspheres were prepared by R. Linhardt and D. Flanagan (University of Iowa) using a coacervation method described by Wang et al. (1991). Release rates were projected to be continuous across 4 weeks, with greatest release in weeks 1 and 4 (Wang et al., 1990). Booster treatment format consisted of a single injection of $65 \mu \mathrm{g}$ PZP $(0.5 \mathrm{ml})$ emulsified with $0.5 \mathrm{ml}$ Freund's incomplete adjuvant.

Each treatment was administered remotely by a dart fired from a rifle. The most reliable delivery was obtained using the Pneu-Dart system (Williamsport, PA), which uses a .22 caliber rifle with scope and powder-charged, $1.0 \mathrm{cc}$, self-injecting darts. All darts were recovered after injection. 


\section{Pregnancy testing and foal counting}

All burros in the study were monitored for effectiveness of treatment and reversibility of treatment as determined by foal counts and by pregnancy testing. Collection of data to determine treatment effect was not begun until 12 months after initial treatment to ensure that pregnancies existing before vaccination were not included. Collection of data to determine reversibility of treatment effect was between 12 and 24 months after the last treatment. Pregnancy was assessed via measurement of concentrations of total faecal oestrogens (TFE), oestrone conjugates $\left(\mathrm{E}_{\mathrm{T}} \mathrm{C}\right)$ and immunoreactive pregnanediolglucuronide-like metabolites (iPdG) in extracts from fresh faeces (Kirkpatrick et al., 1991b). Individually identified treated and control jennies were monitored until they defecated, and samples were immediately collected and kept frozen until assayed. Pregnancy data were generated for up to five faecal collection periods, which were approximately 12, 21, 24, 36 and 48 months after initial PZP vaccination. Pregnancy data are presented as means \pm SEM. Statistical hypothesis testing for foaling data used binomial probability distribution (BPD) and, for pregnancy-test data, used Student's $t$ test or Tukey's test for multiple proportions (Zar, 1984).

\section{Results}

Concentrations of steroid metabolites indicative of pregnancy were compared between burros that produced foals and burros that did not produce foals during the period from February 1993 to February 1994 (Table 1). Two non-foaling burros, one PZP-treated and one control, showed conflicting steroid results (pregnant versus nonpregnant) among sample periods. It is possible that a pregnancy occurred between samplings, but no foals were produced by these burros during the sampling period. The average concentrations (ng $\mathrm{g}^{-1}$ faeces \pm SEM) of faecal steroids in samples from nonfoaling burros $(n=10)$ were $15.4 \pm 1.6$ for TFE, $24.2 \pm 1.8$ for $\mathrm{E}_{1} \mathrm{C}$, and $849.9 \pm 289.1$ for iPdG. In contrast, burros that produced foals $(n=6)$ exhibited average faecal steroid concentrations during pregnancy of $286.5 \pm 100.2$ for TFE, $145.4 \pm 57.6$ for $\mathrm{E}_{1} \mathrm{C}$, and $2950.7 \pm 160.7$ for $\mathrm{iPdG}$. The differences between foaling and nonfoaling burros were significant $(P<0.05$, Student's $t$ test) for all three steroid measures. In PZP-treated and control burros for which reproductive status was known for at least one full gestation period $(n=18)$, pregnancy test data correlated $100 \%$ with eventual presence or absence of foals.

At the beginning of the study (before any treatments), six of the 16 burros scheduled for PZP treatment had offspring ranging from approximately 2 to 12 months of age. By 1 year after treatment, when monitoring for treatment effect was begun, an additional four jennies had produced foals. In the period from 12 to 24 months after PZP treatment, none of the 16 treated burros was observed with a foal, and one burro tested positive for pregnancy at 22 months after immunization (Table 2). In contrast, four of the II control burros were observed with offspring, and six (including three of the above four) of the 11 tested positive for pregnancy during this period. In the four jennies that had been given a booster inoculation after 1 year, there were no positive pregnancy tests and no foals were produced. The proportions of burros producing foals in the PZP-treated versus control groups were different $(P<0.01 ; B P D)$ in the 11-24 months after treatment. In addition, the proportion of burros producing foals before treatment and during the test period for treatment effectiveness (12-24 months) was different $(P<0.01 ; \mathrm{BPD})$. All burros in the study appeared subjectively to remain healthy for the entire study period, based on physical appearance, demeanour and general behaviour as indices of condition.

Reversibility of treatment effect was assessed by faecal pregnancy testing only. For reversibility testing we were able to locate only 13 of 16 treated burros, and six of 11 control burros. Six of $13(46.1 \%)$ PZP-treated and three of six $(50.0 \%)$ control burros tested pregnancy positive (Table 3). Faecal samples were also collected from 33 randomly chosen jennies that were not in the study. Fifteen of these 33 jennies (45.5\%) tested pregnancy positive.

Mating behaviour, which included courtship, female oestrous behaviour, and male mounting and copulatory behaviour (intromission with or without ejaculation) were observed on 21 occasions during the study period. No subjectively discernible differences in reproductive behaviour were observed between PZP-treated and control burros. Breeding was recorded in all months studied. Across 3 years, the approximate frequency of reproductive behaviour occurrence per $100 \mathrm{~h}$ of observation was 7.5 in January, 7.5 in February, 12 in April and 4.5 in November. Observations were not made in other months.

Table 1. Correlation of foal production and total faecal oestrogens (TFE), oestrone conjugates $\left(E_{I} C\right)$ and progesterone metabolites (iPdG) concentrations in feral burros

\begin{tabular}{|c|c|c|c|c|}
\hline \multirow[b]{2}{*}{ Condition $^{\mathrm{a}}$} & \multirow[b]{2}{*}{$n$} & \multicolumn{3}{|c|}{$\begin{array}{l}\text { Faecal steroid concentration } \\
\quad\left(\mathrm{ng} \mathrm{g}^{-1} \text { dry mass } \pm \mathrm{SE} \text { ) }\right.\end{array}$} \\
\hline & & TFE & $\mathrm{E}_{\mathrm{I}} \mathrm{C}$ & $\mathrm{iPdG}$ \\
\hline Burros that produced foals ${ }^{b}$ & 6 & $286.5 \pm 100.2$ & $145.4 \pm 57.6$ & $2950.7 \pm 160.7$ \\
\hline Burros that did not produce foals & 10 & $15.4 \pm 1.6$ & $24.2 \pm 1.8$ & $849.9 \pm 289.1$ \\
\hline
\end{tabular}


Table 2. Effect of pig zonae pellucidae (PZP) immunocontraception on the incidence of pregnancy in free-roaming feral burros

\begin{tabular}{|c|c|c|}
\hline Condition & $n$ & $\begin{array}{c}\text { Number }(\%) \text { of } \\
\text { burros that } \\
\text { were pregnant }\end{array}$ \\
\hline
\end{tabular}

$\begin{array}{lrl}\text { PZP-treated (2 injections) } & 13 & 0(0)^{\mathrm{a}} \\ \text { PZP-treated ( } 1 \text { injection) } & 3 & 1(33.0)^{\mathrm{b}} \\ \text { Untreated control } & 11 & 6(54.4)^{\mathrm{b}}\end{array}$

Pregnancy was determined via measurement of concentrations of total faecal oestrogens (TFE), oestrone conjugates $\left(\mathrm{E}_{\mathrm{I}} \mathrm{C}\right)$ and progesterone metabolites (iPdG) in extracts of faecal samples obtained from individually identified burros. Samples were taken 0-12 months after the last PZP treatment. Values with different superscripts are significantly different from each other; $P<0.05$ Tukey's test for multiple proportions.

Table 3. Reversibility of pig zonae pellucidae (PZP) immunocontraception in free-roaming feral burros

\begin{tabular}{|c|c|c|}
\hline Condition & $n$ & $\begin{array}{c}\text { Number }(\%) \text { of } \\
\text { burros that } \\
\text { were pregnant }\end{array}$ \\
\hline PZP-treated ${ }^{a}$ & 13 & $6(46.1)$ \\
\hline Untreated control & 6 & $3(50.0)$ \\
\hline Random sampling & 33 & $15(45.5)$ \\
\hline
\end{tabular}

Pregnancy was determined via measurement of concentrations of total faecal oestrogens (TFE), oestrone conjugates $\left(\mathrm{E}_{1} \mathrm{C}\right)$ and progesterone metabolites (iPdG). Samples were taken 12-24 months after the last PZP treatment. No significant differences across groups; $P>0.05$, Tukey test for multiple proportions.

Values for jennies given one injection and two injections were pooled, since pregnancy incidence did not differ in these groups.

\section{Discussion}

The results of this study demonstrate that PZP immunocontraception can be delivered to free-roaming feral burros, is highly effective in preventing pregnancy in this species, and is reversible in its effect. As stated previously, the first 12 months after immunization were not included in the assessment of treatment efficacy on the premise that some burros were already pregnant at immunization time. This turned out to be the case for four burros which foaled in the 12 months following immunization. The foals were nursed and grew normally. Since the gestation period is approximately 11 months in burros (McKnight, 1958), these pregnancies had begun prior to the PZP treatment. Thus, in burros, as in other species studied to date (Turner and Kirkpatrick, 1991), PZP contraception does not disrupt existing pregnancies.

The two-injection protocol was more effective than the single-injection, controlled-release PZP protocol in preventing pregnancy. These results are similar to contraceptive effects of the two-injection PZP protocol reported for horses (Kirkpatrick et al., 1990a) and for white-tailed deer (Turner et al., 1992). The refinement of a high-efficacy, single-injection treatment, which is underway, will be necessary before immunocontraception can be used for routine management of burros.

It appears that burros on St John exhibit reproductive behaviour throughout the year. However, the data from the present study showed that breeding frequency is greater in spring than in other seasons. November was a breeding nadir among the months studied. Assuming that the contraceptive effect is of similar duration across treated individuals, the year-round nature of burro reproduction on St John makes it necessary to consider spreading contraceptive treatment across the year. This would prevent the bunching of foal production at one time of year, and ensure a more natural temporal pattern in foaling.

Obtaining access to the burros for treatment was accomplished with high success by the use of bait stations. It was necessary to maintain a regular daily baiting schedule to ensure regular return of burros to the site, and even with a regular baiting schedule, almost $40 \%$ of the burros were not daily visitors. However, over 4-5 days, most study burros would visit their respective bait stations at least once. While almost all burros consumed bait when it was available, a definite pecking order developed regarding consumption of limited bait. At a given station, a few burros would eat the bait while the remainder of the group watched. Placing two or three piles of bait several metres from each other permitted access for more individuals.

Burro family groups appeared to prefer certain limited areas (home ranges) of the island and showed fairly regular patterns of movement within these areas. This is consistent with the findings of Nellis et al. (1986). Among burros in the present study, each home range included at least one drainage basin with a clearing, fresh water supply, and at least $1 \mathrm{~km}$ of dirt or paved road. Some burro groups moved back and forth regularly between two different drainage basins and were observable in the clearings. Many road areas were lined with vegetation that appealed to burros, and they were often observable along the roads. All except two of the jennies in the study remained throughout the 3 year study within the home range where they were first observed. The home-range stability and frequent use of roads and bait stations by burros facilitated the determination of burro identification, movement patterns and habits.

The use of counts of young offspring has been a classic approach to determining fecundity (Seber, 1982; Wolfe et al., 1989). Unfortunately, counts of young can often yield underestimates of reproductive rates and productivity, since fetal losses and neonatal losses, respectively, may be missed (Berger, 1986). On St John, the jennies rarely bring young foals out of the dense bush. Most foals are not seen until they are 2-4 months of age. Thus, counting of foals is not an optimal method for assessing contraceptive effectiveness in St John burros.

In contrast, burro pregnancy testing via measurement of steroid metabolites in faeces appears to be reliable. The differences in faecal steroid concentrations between pregnant and nonpregnant burros were large, ranging from an average of 3.5-fold for iPdG to 18.5-fold for TFE. These differences were similar to those reported in horses (Kirkpatrick et al., $1990 \mathrm{~b}, 1991 \mathrm{~b})$. All burros that produced foals had previously tested positive for pregnancy, and none of the burros that tested negative for pregnancy have produced foals. This 
reliability in testing for pregnancy in burros suggests potential usefulness for assessing various aspects of burro reproduction, including population fertility rates, fetal loss rates, seasonal reproductive patterns and individual oestrous cycles. In two burros showing both pregnancy-positive and pregnancynegative steroid data across their samples, the pregnancypositive data were late in the sample period. These burros may have become pregnant between early and late samples.

In summary, the present study has demonstrated in freeroaming feral burros on St John, which breed all year round that: (1) burros are accessible for PZP treatment by use of bait stations; (2) PZP vaccine can be remotely delivered by dart; (3) PZP vaccine is effective in preventing pregnancy; (4) PZP treatment effect is reversible; and (5) pregnancy can be detected reliably by faecal steroid analysis.

The execution of this project has involved a cooperative effort on the part of the Virgin Islands National Park, The Humane Society of the United States, the Medical College of Ohio, and the Virgin Islands Environmental Resource Station of the University of the Virgin Islands. Special thanks are accorded T. Kelley and J. Bjork of Virgin Islands National Park for their project coordination efforts and field assistance on site. Funding of the project was undertaken by Virgin Islands National Park and the Humane Society of the United States. Special thanks to M. Bernoco for preparation of the PZP vaccine and to E. V. Berkeley for faecal steroid analysis.

\section{References}

Berger J (1986) Wild Horses of the Great Basin: Social Compefition and Population Size University of Chicago Press, Chicago

Florman PM and Wassarman HM (1985) O-linked oligosaccharides of mouse egg ZP3 account for its sperm receptor activity Cell 41 313-324

Kirkpatrick JF, Turner JW, Jr and Perkins A (1982) Reversible fertility control in feral horses Journal of Equine Veterinary Science 2 114-118

Kirkpatrick JF, Liu IKM and Turner JW, Jr (1990a) Remotely-delivered immunocontraception in feral horses Wildlife Society Bulletin 18 326-330

Kirkpatrick JF, Shideler SE and Turner JW, Jr (1990b) Pregnancy determination in uncaptured feral horses based on steroid metabolites in urine-soaked snow and free steroids in feces Canadian Journal of Zoology 68 2576-2579

Kirkpatrick JF, Liu IKM, Turner JW, Jr and Bernoco M (1991a) Antigen recognition in feral mares previously immunized with porcine zonae pellucidae Journal of Reproduction and Fertility Supplement 44 321-325

Kirkpatrick JF, Shideler SE, Lasley BL and Turner JW, Jr. (1991b) Pregnancy determination in uncaptured feral horses by means of fecal steroid conjugates Theriogenology 35 753-759
Lasley BL and Kirkpatrick JF (1991) Monitoring ovarian function in captive and free-ranging wildlife by means of urinary and fecal steroids Journal of Zoo and Wildlife Medicine 22 23-31

Liu IKM, Bernoco M and Feldman M (1989) Contraception in mares heteroimmunized with porcine zona pellucida Journal of Reproduction and Fertility $\mathbf{8 5}$ 19-29

Loskutoff NM, Ott JE and Lasley BL (1982) Urinary steroid evaluations to monitor ovarian function in exotic ungulates I. Pregnanediol-3-glucuronide immunoreactivity in the okapi (Okapia johnstoni) Zoo Biology 1 45-53

McKnight TL (1958) The feral burro in the United States Journal of Wildlife Management 22 163-178

Nellis DW, Rudman R and Swanbeck B (1986) The Behavior and Ecology of Feral Burros on St John, US Virgin Islands Draft Report for Virgin Islands Department of Conservation and Cultural Affairs, St Thomas, USVI

Plotka ED, Vevea DN, Eagel TC, Tester JR and Siniff DB (1989) Effective contraception in feral horses using homogenous Silastic implants containing ethinylestradiol $\left(\mathrm{EE}_{2}\right)$ or $\mathrm{EE}_{2}$ plus progesterone Biology of Reproductive 40 (Supplement) 169a

Sacco AG, Subramanian MG and Yurewicz EC (1984) Association of sperm receptor activity with a purified pig zona antigen (PPZA) Journal of Reproduction Immunology 6 89-103

Seber GA (1982) The Estimation of Animal Abundance (2nd Edn) MacMillan Publishing Co., New York

Skinner SM, Mills T, Kirchick HJ, and Dunbar BS (1984) Immunization with zona pellucida proteins results in abnormal ovarian follicular differentiation and inhibition of gonadotropin-induced steroid secretion Endocrinology 115 2418-2432

Turner JW, Jr, Perkins A and Kirkpatrick JF (1981) Elimination marking behavior in feral horses Canadian Journal of Zoology 59 1561-1566

Turner JW, Jr and Kirkpatrick JF (1982) Androgens, behavior and fertility control in feral stallions Journal of Reproduction and Fertility Supplement 32 79-87

Turner JW, Jr and Kirkpatrick JF (1991) New developments in feral horse contraception and their potential application to wildlife Wildife Society Bulletin 19 350-359

Turner JW, Jr, Liu IKM and Kirkpatrick JF (1992) Remotely delivered immunocontraception in captive white-tailed deer Journal of Wildlife Management 56 154-157

Wang HT, Palmer H, Linhardt RJ, Flanagan DR and Schmitt E (1990) Degradation of poly(ester) microspheres Biomaterials 11 679-685

Wang HT, Schmitt E, Flanagan DR and Linhardt R] (1991) Influence of formulation methods in the in vitro controlled release of protein from poly(ester) microspheres Journal of Controlled Release 17 23-32

Wolfe ML, Ellis LC and MacMullen R (1989) Reproductive rates of feral horses and burros Journal of Wildlife Management 53 916-924

Woodward SL (1979) Population control in feral burros - does it occur? Journal of Colorado and Wyoming Academic Sciences 1187

Zar JH (1984) Biostatistical Analysis (2nd edn) Prentice-Hall, Englewood Cliffs 